\title{
MAKNA HUKUM PADA PRINSIP TATA KELOLA PERSPEKTIF PENGADAAN VAKSIN DAN PELAKSANAAN VAKSINASI COVID-19
}

Oleh :

Dr. I Nyoman Prabu Buana Rumiartha, SH. MH.

( Fakultas Hukum Dan Humaniora, Universitas Bali Dwipa, Jalan Pulau Flores

Nomor 5 Denpasar. Email : rbp.prabu@gmail.com )

\begin{abstract}
Abstrak, Peraturan Presiden Republik Indonesia Nomor 14 Tahun 2021 Tentang Perubahan Atas Peraturan Presiden Nomor 99 Tahun 2020 tentang Pengadaan Vaksin dan Pelaksanaan Vaksinasi dalam Rangka Penanggulangan Pandemi Corona COVID-19 (Perpres 14/2021) telah diterbitkan oleh Presiden. Perpres tersebut diterbitkan untuk pengadaan vaksin serta pelaksanaan vaksinasi COVID-19 di Indonesia. Pada ketentuan Pasal 11 Ayat (1) Dalam hal terjadi keadaan kahar (force majeure) sebagaimana tercantum dalam kontrak atau kerjasama dan/atau kegagalan pemberian persetujuan penggunaan pada masa darurat (emergency use authorization) atau penerbitan Nomor lzin Edar (NIE) Vaksin COVID-19, pelaksanaan kontrak atau kerjasama dalam pengadaan VaksinCOVID-19 dapat dihentikan. Berikutnya pada Pasal 11 Ayat (2) Keadaan kahar (force majeure) sebagaimana dimaksud pada ayat (1) merupakan suatu keadaan yang terjadi di luar kehendak para pihak dalam kontrak atau kerjasama dan tidak dapat diperkirakan sebelumnya, sehingga kewajiban yang ditentukan dalam kontrak atau kerjasama menjadi tidak dapat dipenuhi meliputi keseluruhan proses pengadaan Vaksin COVID-19 termasuk penyerahan Vaksin COVID- 19. Selanjutnya pada Pasal 11 Ayat (3) Dalam hal pelaksanaan kontrak atau kerjasama sebagaimana dimaksud pada ayat (1) dilanjutkan, para pihak dapat melakukan perubahan kontrak atau kerjasama dengan mengacu prinsip tata kelola yang baik. Khusus pada ketentuan Pasal 11 ayat (3) Perpres 14/2021 pada frasa "prinsip tata kelola" dalam hal ini makna hukum pada frasa "prinsip tata kelola" tersebut menimbulkan kekaburan norma (vague norm) yang berakibat pada timbulnya ketidakpastian hukum terhadap pengaturan pasal tersebut yang tidak menjelaskan apa yang dimaksud dengan prinsip tata kelola. Bahwa dapat disebut mengandung tafsir suatu norma yang kabur dalam hal ini diperkuat dengan tidak adanya suatu penjelasan yang signifikan dan atau suatu penjelasan yang lugas dan terarah untuk menjelaskan suatu makna "prinsip tata kelola". Makna pada frasa "prinsip tata kelola" tersebut dapat menimbulkan kekaburan norma (vague norm) yang berakibat pada timbulnya ketidakpastian hukum terhadap pengaturan Pasal 11 ayat (3) Perpres 14/2021, maka diperlukannya suatu revisi terhadap pengaturan Pasal 11 ayat (3) Perpres 14/2021 terkait Pengadaan Vaksin dan Pelaksanaan Vaksinasi dalam Rangka Penanggulangan Pandemi Corona COVID-19.
\end{abstract}

\section{Kata Kunci : Makna Hukum, Prinsip Tata Kelola, Pengadaan Vaksin, Pelaksanaan Vaksinasi, COVID-19.}

Abstract, Presidential Regulation of the Republic of Indonesia Number 14 of 2021 concerning Amendments to Presidential Regulation Number 99 of 2020 concerning Vaccines Procurement and Implementation of Vaccinations in the Context of the Corona COVID-19 Pandemic (Perpres 14/2021) has been issued by the President. The Presidential Decree was issued for the procurement of vaccines and the implementation of the COVID19 vaccination in Indonesia. In the provisions of Article 11 Paragraph (1) In the event of force majeure as stated in the contract or cooperation and / or failure to grant approval for use during an emergency (emergency use authorization) or issuance of a Covid-19 
Vaccine License Number (NIE), the implementation of contracts or cooperation in the procurement of the COVID-19 Vaccine can be stopped. Next, in Article 11 Paragraph (2) Force majeure as referred to in paragraph (1) is a situation that occurs outside the will of the parties in the contract or cooperation and cannot be predicted in advance, so that the obligations specified in the contract or cooperation become cannot be fulfilled covering the entire process of procurement of the COVID-19 Vaccine including delivery of the COVID-19 Vaccine.Furthermore, Article 11 Paragraph (3) In the event that the implementation of the contract or cooperation as referred to in paragraph (1) is continued, the parties can make changes to the contract or cooperation with refers to the principles of good governance. Especially in the provisions of Article 11 paragraph (3) of Presidential Decree 14/2021 on the phrase "principles of governance " in this case the legal meaning of the phrase "principles of governance " creates vague norms which result in legal uncertainty over regulations. that article which does not explain what is meant by the principles of governance. That it can be said to contain a vague interpretation of a norm, in this case it is strengthened by the absence of a significant explanation and / or a direct and straightforward explanation to explain a meaning of "governance principles". The meaning of the phrase "principles of governance " can lead to vague norms resulting in legal uncertainty over the regulation of Article 11 paragraph (3) of Presidential Decree 14/2021, so a revision is needed to regulate Article 11 paragraph (3) of the Presidential Decree. 14/2021 regarding Vaccines Procurement and Implementation of Vaccinations in the Context of the Corona COVID-19 Pandemic.

\section{Keywords: Legal Meanings, Governance Principles, Vaccine Procurement, Vaccination Implementation, COVID-19.}

\section{Latar Belakang Masalah.}

Bahwa pada Desember 2019, kasus pneumonia misterius pertama kali dilaporkan di Wuhan, Provinsi Hubei. Sumber penularan kasus ini masih belum diketahui pasti, tetapi kasus pertama dikaitkan dengan pasar ikan di Wuhan. Tanggal 18 Desember hingga 29 Desember 2019, terdapat lima pasien yang dirawat dengan Acute Respiratory Distress Syndrome (ARDS). Sejak 31 Desember 2019 hingga 3 Januari 2020 kasus ini meningkat pesat, ditandai dengan dilaporkannya sebanyak 44 kasus. Tidak sampai satu bulan, penyakit ini telah menyebar di berbagai provinsi lain di China, Thailand, Jepang, dan Korea Selatan. ${ }^{1}$

Sampel yang diteliti menunjukkan etiologi coronavirus baru. Awalnya, penyakit ini dinamakan sementara sebagai 2019 novel

1 C. Martin Rumende, Coronavirus Disease 2019: Tinjauan Literatur Terkini, coronavirus (2019-nCoV), kemudian WHO mengumumkan nama baru pada 11 Februari 2020 yaitu Coronavirus Disease (COVID-19) yang disebabkan oleh virus Severe Acute Respiratory Syndrome Coronavirus-2 (SARS-CoV-2). Virus ini dapat ditularkan dari manusia ke manusia dan telah menyebar secara luas di China dan lebih dari 190 negara dan teritori lainnya.Pada 12 Maret 2020, WHO mengumumkan COVID-19 sebagai pandemik. Hingga tanggal 29 Maret 2020, terdapat 634.835 kasus dan 33.106 jumlah kematian di seluruh dunia. ${ }^{2}$

Coronavirus adalah virus RNA dengan ukuran partikel 120-160 nm. Virus ini utamanya menginfeksi hewan, termasuk di antaranya adalah kelelawar dan unta. Sebelum terjadinya wabah COVID-19, ada 6 jenis coronavirus yang dapat menginfeksi manusia, yaitu alphacoronavirus $229 \mathrm{E}$, alphacoronavirus

Jurnal Penyakit Dalam Indonesia | Vol. 7, No. 1 | Maret 2020.

${ }^{2}$ Ibid., 
NL63, betacoronavirus OC43, betacoronavirus HKU1, Severe Acute Respiratory Illness Coronavirus (SARSCoV), dan Middle East Respiratory Syndrome Coronavirus (MERS-CoV). ${ }^{3}$

Coronaviruses (CoV) adalah keluarga besar virus yang menyebabkan penyakit mulai dari flu biasa hingga penyakit yang lebih parah seperti Sindrom Pernafasan Timur Tengah (MERS-CoV) dan SindromPernafasan Akut Parah (SARS-CoV). Penyakit Coronavirus 2019 (COVID-19) adalah virus corona jenis baru yang ditemukan pada tahun 2019 dan belum pernah teridentifikasi pada manusia (Gugus Tugas Percepatan Penanganan COVID19 Republik Indonesia).

Bahwa di Indonesia Infrastruktur hukum terkait kebijakan penanganan pandemic Covid-19 telah dikeluarkan oleh Presiden berupa Peraturan Pemerintah Pengganti Undang-Undang (Perppu) Nomor 1 Tahun 2020 tentang Kebijakan Keuangan Negara dan Stabilitas Sistem Keuangan untuk Penanganan Pandemi Coronavirus Disease-2019 (Covid-19), dan DPR pun telah menyetujuinya menjadi undangundang.

Selain itu Presiden Joko Widodo telah meresmikan Peraturan Presiden Nomor 82 Tahun 2020 tentang Komite Penanganan Corona Virus Disease 2019 (Covid-19) dan Pemulihan Ekonomi Nasional. Komite ini terdiri dari dua satuan tugas, yakni satuan tugas penanganan Covid-19 dan satuan tugas pemulihan ekonomi nasional. Terbentuknya komite ini diharapkan mampu memperbaiki kinerja pemerintah dalam menangani penanganan Covid-19 sekaligus memulihkan kehidupan ekonomi yang anjlok terhempas badai pandemi. Walaupun bukan tugas ringan tentunya untuk menuntaskan masalah

${ }^{3}$ Riedel S, Morse S, Mietzner T, Miller S. Jawetz, Melnick, \& Adelberg's Medical Microbiology. 28th ed. New kesehatan di satu sisi dan memulihkan ekonomi akibat dampak pandemi di sisi lain.

Namun saat terbitnya Peraturan Presiden Republik Indonesia Nomor 14 Tahun 2021 Tentang Perubahan Atas Peraturan Presiden Nomor 99 Tahun 2020 tentang Pengadaan Vaksin dan Pelaksanaan Vaksinasi dalam Rangka Penanggulangan Pandemi Corona COVID-19 (Perpres 14/2021) untuk pengadaan vaksin serta pelaksanaan vaksinasi COVID-19 di Indonesia dapat ditelusuri Pada ketentuan Pasal 11 Ayat (1) Dalam hal terjadi keadaan kahar (force majeure) sebagaimana tercantum dalam kontrak atau kerjasama dan/atau kegagalan pemberian persetujuan penggunaan pada masa darurat (emergency use authorization) atau penerbitan Nomor lzin Edar (NIE) Vaksin COVID-19, pelaksanaan kontrak atau kerjasama dalam pengadaan VaksinCOVID-19 dapat dihentikan.

Berikutnya pada Pasal 11 Ayat

(2) Keadaan kahar (force majeure) sebagaimana dimaksud pada ayat (1) merupakan suatu keadaan yang terjadi di luar kehendak para pihak dalam kontrak atau kerjasama dan tidak dapat diperkirakan sebelumnya, sehingga kewajiban yang ditentukan dalam kontrak atau kerjasama menjadi tidak dapat dipenuhi meliputi keseluruhan proses pengadaan Vaksin COVID-19 termasuk penyerahan Vaksin COVID19.

Selanjutnya pada Pasal 11 Ayat (3) Dalam hal pelaksanaan kontrak atau kerjasama sebagaimana dimaksud pada ayat (1) dilanjutkan, para pihak dapat melakukan perubahan kontrak atau kerjasama dengan mengacu prinsip tata kelola yang baik.

Khusus pada ketentuan Pasal 11 ayat (3) Perpres 14/2021 pada frasa

York: McGraw-Hill Education/Medical; 2019. hlm.617-22.15 (Terjemahan Bebas). 
"prinsip tata kelola" dalam hal ini makna hukum pada frasa "prinsip tata kelola" tersebut menimbulkan kekaburan norma (vague norm) yang berakibat pada timbulnya ketidakpastian hukum terhadap pengaturan pasal tersebut yang tidak menjelaskan apa yang dimaksud dengan prinsip tata kelola. Bahwa dapat disebut mengandung tafsir suatu norma yang kabur dalam hal ini diperkuat dengan tidak adanya suatu penjelasan yang signifikan dan atau suatu penjelasan yang lugas dan terarah untuk menjelaskan suatu makna "prinsip tata kelola". Makna pada frasa "prinsip tata kelola" tersebut dapat menimbulkan kekaburan norma (vague norm) yang berakibat pada timbulnya ketidakpastian hukum terhadap pengaturan Pasal 11 ayat (3) Perpres 14/2021, maka diperlukannya suatu revisi terhadap pengaturan Pasal 11 ayat (3) Perpres 14/2021 terkait Pengadaan Vaksin dan Pelaksanaan Vaksinasi dalam Rangka Penanggulangan Pandemi Corona COVID-19.

\section{Rumusan Masalah}

Bagaimana penjelasan substansi makna hukum terhadap Pasal 11 ayat (3) Perpres 14/2021 terkait Prinsip Tata Kelola pada Pengadaan Vaksin dan Pelaksanaan Vaksinasi COVID-19?

\section{Metode Penelitian.}

Penelitian ini menggunakan tipe penelitian hukum yuridis normatif yaitu mengkaji dan menganalisa bahan-bahan serta isue-isue hukum berdasarkan peraturan perundang-undangan. Penelitian ini dilakukan untuk memecahkan permasalahan hukum yang timbul sedangkan hasil yang akan di capai adalah preskripsi mengenai apa yang seyogyanya dilakukan. ${ }^{4}$ Dalam hal ini penelitian penjelasan substansi makna hukum terhadap Pasal 11 ayat (3) Perpres 14/2021 terkait Prinsip Tata

4 Peter Mahmud Marzuki, 2005, Penelitian hukum, Prenada Media, Jakarta, Hlm. 7.
Kelola pada Pengadaan Vaksin dan Pelaksanaan Vaksinasi COVID-19.

Metode pendekatan yang dipergunakan dalam penelitian ini menggunakan beberapa teknik sebagai berikut:

a. Pendekatan Undang-Undang (Statute Aproach)

Yaitu pendekatan dengan menggunakan legislasi dan regulasi. Penelitian hukum dalam level dogmatika hukum tidak dapat melepaskan diri dari pendekatan perundang-undangan karena pokok bahasan yang di telaah berasal dari peraturan perundang-undangan. Pendekatan undang-undang dilakukan dengan menelaah semua undang-undang dan regulasi yang bersangkut paut dengan penjelasan substansi makna hukum terhadap Pasal 11 ayat (3) Perpres 14/2021 terkait Prinsip Tata Kelola pada Pengadaan Vaksin dan Pelaksanaan Vaksinasi COVID-19.

b. Pendekatan konseptual (Conseptual Aproach)

Yaitu pendekatan yang beranjak dari pandangan-pandangan dan doktrindoktrin yang berkembang di dalam ilmu hukum, agar menemukan ide-ide yang melahirkan pengertian-pengertian hukum, dan asas-asas hukum atau argumentasi hukum yang merupakan sandaran peneliti untuk membangun argumentasi hukum dalam memecahkan isu yang dihadapi. ${ }^{5}$ Pendekatan konseptual ini digunakan untuk menemukan pandangan-pandangan dan doktrin-doktrin yang berkembang dalam ilmu hukum, kajian prinsip-prinsip hukum berkaitan dengan penjelasan substansi makna hukum terhadap Pasal 11 ayat (3) Perpres 14/2021 terkait Prinsip Tata Kelola pada Pengadaan Vaksin dan Pelaksanaan Vaksinasi COVID-19.

\section{Landasan Teori.}

${ }^{5}$ Ibid., 


\section{Teori Negara Hukum.}

Negara berdasarkan atas hukum ditandai oleh beberapa unsur antara lain semua perbuatan atau tindakan pemerintah atau negara harus didasarkan pada ketentuan hukum yang sudah ada sebelum perbuatan atau tindakan itu dilakukan. ${ }^{6}$ Negara Indonesia adalah negara hukum (Rechtstaat), hal ini sebagaimana disebutkan di dalam ketentuan Pasal 1 ayat (3) UndangUndang Dasar Negara Republik Indonesia (UUD NRI 1945).

Para pakar ilmu sosial yang mempunyai suatu minat berprofesional terhadap kata hukum tersebut mendapati kesukaran untuk menangkap esensi hukum dalam suatu bahasa yang sederhana. Menurut Emanuel Kant bahwa tidak ada seorang yuris pun mampu membuat suatu definisi hukum yang tepat. ${ }^{7}$

Pada konstitusi suatu negara menggambarkan secara jelas dalam isi konstitusi itu menurut Mr. J. G Steenbeek, bahwa isi konstitusi itu pada dasarnya adalah adanya jaminan terhadap hak-hak suatu manusia dan warga negaranya, ditetapkan susunan ketatanegaraan suatu negara yang bersifat fundamental, adanya pembagian dan pembatasan tugas ketatanegaraan yang juga bersifat fundamental.

Negara hukum yang dianut oleh Indonesia pada dasarnya bukannya negara hukum yang statis, melainkan negara hukum yang dinamis selalu mengikuti menyesuaikan dengan perkembangan zaman dan kebutuhan masyarakatnya. Hal ini menunjukan bahwa dinamika kehidupan negara dan masyarakat haruslah dapat diantisipasi dan direspon serta dituangkan dalam

\footnotetext{
${ }^{6}$ Sugiyanto dan Bambang Giyanto, 2008, Hukum Administrasi Negara, Lembaga Administrasi Negara-Republik Indonesia, Jakarta, hlm. 11.
}

konstitusi negara dengan melakukan perubahan (amandemen) terhadap undang-undang dasar (UUD) negara dalam berbagai peraturan perundangundangan.

Negara Hukum adalah negara yang berlandaskan hukum dan menjamin keadilan bagi warganya. Maksudnya adalah segala kewenangan dan tindakan alat-alat perlengkapan negara atau penguasa semata-mata berdasarkan hukum atau dengan kata lain diatur oleh hukum. Hal yang demiikian akan mencerminkan keadilan bagi pergaulan hidup warganya. ${ }^{8}$

Negara hukum dalam hal ini adanya suatu produk peraturan perundang-undangan sebagai dasar hukum dalam mengatur berbangsa bernegara. Dalam konteks Pengadaan Vaksin dan Pelaksanaan Vaksinasi dalam Rangka Penanggulangan Pandemi Corona COVID-19 Di Indonesia, diterbitkannya Peraturan Presiden Republik Indonesia Nomor 14 Tahun 2021 Tentang Perubahan Atas Peraturan Presiden Nomor 99 Tahun 2020 tentang Pengadaan Vaksin dan Pelaksanaan Vaksinasi dalam Rangka Penanggulangan Pandemi Corona COVID-19 (Perpres 14/2021).

\section{Hasil Penelitian}

$$
\text { Bahwa hukum bertujuan }
$$

mengintegrasikan dan
mengkoordinasikan berbagai kepentingan dalam masyarakat. Perlindungan hukum harus melihat tahapan yakni perlindungan hukum lahir dari suatu ketentuan hukum dan segala peraturan hukum yang diberikan oleh masyarakat yang pada dasarnya merupakan kesepakatan masyarakat tersebut untuk mengatur hubungan

7 Ahmad Ali, 2012, Menguak Teori Hukum dan Teori Peradilan, Kharisma Putra Utama, hlm. 40.

${ }^{8}$ Abu Daud Busro dan Abu Bakar Busro, 2003, Asas-asas Hukum Tata Negara, Ghoila Indonesia, Jakarta, hlm. 111. 
prilaku antara anggota-anggota
masyarakat. ${ }^{9}$

Hukum harus diciptakan dengan tujuan melindungi kepentingan masyarakat, dengan cara mengintegrasikan dan mengkoordinasikan kepentingankepentingan tersebut. Hukum melindungi hak-hak masyarakat dengan cara mengalokasikan suatu kekuasaan kepada mereka untuk bertindak, misalnya tindakan hukum untuk menuntut melalui institusi hukum, agar hak mereka terpenuhi. ${ }^{10}$

Hukum sebagai perlindungan kepentingan manusia berbeda dengan norma-norma yang lain. Karena hukum itu berisi perintah dan atau larangan, serta membagi hak dan kewajiban. Sudikno Mertokusumo mengemukakan tidak hanya tentang tujuan hukum, tetapi juga tentang fungsi hukum dan perlindungan hukum. Ia berpendapat bahwa :

"dalam fungsinya sebagai perlindungan kepentingan manusia hukum mempunyai tujuan . Hukum mempunyai sasaran yang hendak dicapai adapun tujuan pokok hukum adalah menciptakan ketertiban dan keseimbangan. Dengan tercapainya ketertiban di dalam masyarakat diharapkan kepentingan manusia akan terlindung. Dalam mencapai tujuannya itu hukum bertugas membagi hak dan kewajiban antar perorangan di dalam masyarakat, membagi wewenang dan mengatur cara memecahkan masalah hukum serta memelihara kepastian hukum."11

9 Satjipto Raharjo,2000, Ilmu Hukum, PT. Citra Aditya Bakti, Bandung, hlm.53. 10 Dyah Ochtorina Susanti, 2011, Teori Perlindungan Hukum, Teori Hukum, Program Pasca Sarjana Ilmu Hukum Universitas Islam Kadiri (UNISKA), Kediri, hlm. 4.
Ada tiga hal yang dapat dianalisa dari pandangan Sudikno Mertokusomo. Ketiga hal itu, meliputi fungsi hukum, tujuan hukum, dan tugas hukum.

Roscoe Pound dikutip oleh Sudikno Mertokusumo menyatakan bahwa hukum adalah lembaga terpenting dalam melaksanakan kontrol sosial dan atau rekayasa sosial. Pound pun mengakui bahwa fungsi lain dari hukum adalah sebagai sarana untuk melakukan rekayasa sosial (social engineering). Ia mengatakan bahwa sistem hukum mencapai tujuan ketertiban hukum dengan mengakui kepentingan-kepentingan itu, dengan menentukan batasanbatasan pengakuan atas kepentingan-kepentingan tersebut dan aturan hukum yang dikembangkan serta diterapkan oleh proses peradilan memiliki dampak positif serta dilaksanakan melalui prosedur yang berwibawa, juga berusaha menghormati berbagai kepentingan sesuai dengan batasbatas yang diakui dan ditetapkan. ${ }^{12}$

Hukum telah menentukan pola perilaku tertentu, maka tiap orang seharusnya berperilaku sesuai pola yang telah ditentukan tersebut. Senada dengan Hans Kelsen, Gustav Radbruch berpandangan bahwa hukum harus mengandung 3 (tiga) nilai identitas, yakni asas kepastian hukum (rechtmatigheid), asas keadilan hukum (gerectigheid), dan asas kemanfaatan hukum (zwechtigheid). ${ }^{13}$

\footnotetext{
${ }^{11}$ Sudikno Mertokusumo,1999, Mengenal hukum Suatu Pengantar, Liberty, Yogyakarta, hlm 71.

${ }^{12}$ Lili Rasjidi \& Ira Thania Rasjidi,2002, Pengantar Filsafat Hukum, Mandar Maju, Bandung, hlm. 74.

${ }^{13}$ Bernard L. Tanya, 2010, Teori Hukum Strategi Tertib Manusia Lintas Ruang
} 
Penjelasan teori hukum tersebut terkait dengan isi substansi pengaturan pada Pasal 11 Ayat (3) Dalam hal pelaksanaan kontrak atau kerjasama sebagaimana dimaksud pada ayat (1) dilanjutkan, para pihak dapat melakukan perubahan kontrak atau kerjasama dengan mengacu prinsip tata kelola yang baik.

Khusus pada ketentuan Pasal 11 ayat (3) Perpres 14/2021 pada frasa "prinsip tata kelola" dalam hal ini makna hukum pada frasa "prinsip tata kelola" tersebut menimbulkan kekaburan norma (vague norm) yang berakibat pada timbulnya ketidakpastian hukum terhadap pengaturan pasal tersebut yang tidak menjelaskan apa yang dimaksud dengan prinsip tata kelola. Bahwa dapat disebut mengandung tafsir suatu norma yang kabur dalam hal ini diperkuat dengan tidak adanya suatu penjelasan yang signifikan dan atau suatu penjelasan yang lugas dan terarah untuk menjelaskan suatu makna "prinsip tata kelola". Makna pada frasa "prinsip tata kelola" tersebut dapat menimbulkan kekaburan norma (vague norm) yang berakibat pada timbulnya ketidakpastian hukum terhadap pengaturan Pasal 11 ayat (3) Perpres 14/2021.

Bahwa dari penjelasan tersebut menurut hemat penulis perlunya direvisi frasa khususnya pada pengaturan Pasal 11 ayat (3) Perpres 14/2021 tersebut. Alasan penulis tersebut berdasarkan pada metode interprestasi atau penafsiran hermeneutika yuridis yaitu metode untuk menafsirkan terhadap teks perundangundangan yang tidak jelas, agar perundang-undangan tersebut dapat diterapkan terhadap peristiwa konkrit tertentu ${ }^{14}$ pada konteks ini perlunya interprestasi atau penafsiran diperlukan

dan Generasi, Genta Publishing, Yogyakarta, hlm.127.

${ }^{14}$ Bambang Sutiyoso, 2012, Metode Penemuan Hukum : Upaya Mewujudkan Hukum yang Pasti dan Berkeadilan, UII untuk menafsirkan terhadap teks perundang-undangan yang tercantum pada pengaturan Pasal 11 ayat (3) Perpres 14/2021, bahwa yang sebelumnya di sebutkan "mengacu prinsip tata kelola yang baik', maka sebaiknya dirubah menjadi "mengacu prinsip tata kelola yang baik berdasarkan....., dalam hal ini perjelas maksud dari Prinsip Tata Kelola yang baik berdasarkan apa saja... Selain itu diperlukannya metode eksposisi / kontruksi hukum yaitu metode yang mejelaskan kata-kata atau membentuk pengertian (hukum), pengertian hukum yang dimaksud adalah konstruksi hukum (rechts constructie) yang merupakan alat-alat yang dipakai untuk menyusun bahan hukum yang dilakukan secara sistematis dalam bentuk istilah yang baik. ${ }^{15}$ Pentingnya konstruksi hukum (rechts constructie) agar makna hukum pada frasa "prinsip tata kelola" tersebut dapat kejelasan makna hukum terhadap pengaturan Pasal 11 ayat (3) Perpres 14/2021 terkait Pengadaan Vaksin dan Pelaksanaan Vaksinasi COVID-19.

\section{Kesimpulan.}

Pasal 11 Ayat (3) Dalam hal pelaksanaan kontrak atau kerjasama sebagaimana dimaksud pada ayat (1) dilanjutkan, para pihak dapat melakukan perubahan kontrak atau kerjasama dengan mengacu prinsip tata kelola yang baik.

Khusus pada ketentuan Pasal 11 ayat (3) Perpres 14/2021 pada frasa "prinsip tata kelola" dalam hal ini makna hukum pada frasa "prinsip tata kelola" tersebut menimbulkan kekaburan norma (vague norm) yang berakibat pada timbulnya ketidakpastian hukum terhadap pengaturan pasal tersebut yang tidak menjelaskan apa yang dimaksud

Press, Cet. Keempat, Yogyakarta, Hlm. 135.

${ }^{15}$ Sudikno Mertokusumo, 1996, Mengenal Hukum Suatu Pengantar, Liberty, Yogyakarta, Hlm.69. 
dengan prinsip tata kelola. Bahwa dapat disebut mengandung tafsir suatu norma yang kabur dalam hal ini diperkuat dengan tidak adanya suatu penjelasan yang signifikan dan atau suatu penjelasan yang lugas dan terarah untuk menjelaskan suatu makna "prinsip tata kelola". Makna pada frasa "prinsip tata kelola" tersebut dapat menimbulkan kekaburan norma (vague norm) yang berakibat pada timbulnya ketidakpastian hukum terhadap pengaturan Pasal 11 ayat (3) Perpres 14/2021.

Bahwa dari penjelasan tersebut menurut hemat penulis perlunya direvisi frasa khususnya pada pengaturan Pasal 11 ayat (3) Perpres 14/2021 tersebut, bahwa yang sebelumnya di sebutkan "mengacu prinsip tata kelola yang baik", maka sebaiknya dirubah menjadi "mengacu prinsip tata kelola yang baik berdasarkan....., dalam hal ini perjelas maksud dari Prinsip Tata Kelola yang baik berdasarkan apa saja... Selain itu diperlukannya metode eksposisi / kontruksi hukum yaitu metode yang mejelaskan kata-kata atau membentuk pengertian (hukum), pengertian hukum yang dimaksud adalah konstruksi hukum (rechts constructie) yang merupakan alat-alat yang dipakai untuk menyusun bahan hukum yang dilakukan secara sistematis dalam bentuk istilah yang baik. Pentingnya konstruksi hukum (rechts constructie) agar makna hukum pada frasa "prinsip tata kelola" tersebut dapat kejelasan makna hukum terhadap pengaturan Pasal 11 ayat (3) Perpres 14/2021 terkait Pengadaan Vaksin dan Pelaksanaan Vaksinasi COVID-19.

\section{Rekomendasi}

Rekomendasi penelitian ini yakni diperlukannya suatu revisi terhadap pengaturan pada Pasal 11 ayat (3) Perpres 14/2021 terkait Pengadaan Vaksin dan Pelaksanaan Vaksinasi COVID-19, berdasarkan metode interprestasi atau penafsiran hermeneutika yuridis yaitu metode untuk menafsirkan terhadap teks perundang- undangan yang tidak jelas, agar perundang-undangan tersebut dapat diterapkan terhadap peristiwa konkrit tertentu.

\section{DAFTAR PUSTAKA}

Abu Daud Busro dan Abu Bakar Busro, 2003, Asas-asas Hukum Tata Negara, Ghoila Indonesia, Jakarta.

Ahmad Ali, 2012, Menguak Teori Hukum dan Teori Peradilan, Kharisma Putra Utama, Jakarta.

Bernard L. Tanya, 2010, Teori Hukum Strategi Tertib Manusia Lintas Ruang dan Generasi, Genta Publishing, Yogyakarta.

Bambang Sutiyoso, 2012, Metode Penemuan Hukum : Upaya Mewujudkan Hukum yang Pasti dan Berkeadilan, UII Press, Cet. Keempat, Yogyakarta.

C. Martin Rumende, Coronavirus Disease 2019: Tinjauan Literatur Terkini, Jurnal Penyakit Dalam Indonesia | Vol. 7, No. 1 | Maret 2020.

Dyah Ochtorina Susanti, 2011, Teori Perlindungan Hukum, Teori Hukum, Program Pasca Sarjana Ilmu Hukum Universitas Islam Kadiri (UNISKA), Kediri.

Lili Rasjidi \& Ira Thania Rasjidi,2002, Pengantar Filsafat Hukum, Mandar Maju, Bandung.

Peter Mahmud Marzuki, 2005, Penelitian hukum, Prenada Media, Jakarta.

Riedel S, Morse S, Mietzner T, Miller S. Jawetz, Melnick, \& Adelberg's Medical Microbiology. 28th ed. New York: McGraw-Hill Education/Medical; 2019. 
Soerjono Soekanto dan Purnadi Purbacaraka, 1994, Aneka Cara Pembedaan Hukum, PT Citra Aditya Bakti, Bandung.

Sudikno Mertokusumo, 1996, Mengenal Hukum Suatu Pengantar, Liberty, Yogyakarta.
Satjipto Raharjo,2000, Ilmu Hukum, PT. Citra Aditya Bakti, Bandung.

Sugiyanto dan Bambang Giyanto, 2008, Hukum Administrasi Negara, Lembaga Administrasi Negara-Republik Indonesia, Jakarta. 